\title{
EVALUASI KEMAMPUAN LAHAN KECAMATAN KEDAWUNG KABUPATEN SRAGEN JAWA TENGAH
}

\author{
Oleh: \\ Drs. Kuswaji Dwi Priyono \\ Dra. Alif Noor Anna \\ Dra. Retno Woro Kaeksi
}

\begin{abstract}
This research aims to apply and to evaluate land capability and to map the classes of land capability in Kedawung Sub district Sragen district, Central Java Province. The research result is presented on land capability class map on scale 1:50.000

The classification of land capability classes in copied from Soepraptohardjo, 1962 (by modification). It is based on the score of land factors. The Land factors consist of advantegeous factor and disadvantageous factors, and it are valuated on each land unit. The land use unit is interpreted from topographical map, geological map and field work. Base on the classification, the reseach area is classified in three land capability class:

Class I: 2,375 Ha (49.1\%), Class II 2,400 Ha (49.6\%), and class IV 62,5 $\mathrm{Ha}$ (1.3\%). Class I is distributed on lowly eroded fluvial basim and lowly eroded volcanic foot slope. Class II is distribution on moderatelly eroded fluvial basim and moderately eroded volcanic bottom slope. Class IV is distributed on strongly eroded fluvial basim.

The inhibiting factors of land capability on class II are erosion and slope, and on class IV are erosion, slope, soil, and rock. Base on this factors. The land is classified on sub class II el and subclass IV elsb.
\end{abstract}

\section{INTISARI}

Penelitian ini bertujuan untuk mengklasifikasi dan mengevaluasi kelas kemampuan laban, serta memetakan kelas kemampuan laban Kecamatan Kedawung, Kabupaten Sragen, Jawa Tengah. Hasil akbir disajikan dalam Peta Kelas Kemampuan Lahan skala 1: 50.000

Klasifikasi kelas kemampuan laban didasarkan pada jumlab skor faktor-faktor laban yang menguntungkan dan yang merugikan dari metoda Soepraptobardjo (1962 dengan modifikasi). Faktor-faktor laban tersebut dinilai pada setiap satuan bentuk laban. Satuan bentuk laban diperoleb melalut interpretasi peta topografi, peta geologi dan pengamatan lapangan.

Dari basil klasifikasi didapatkan bahwa daerab penelitian seluas 2375 bektar $(49,1 \%)$ mempunyai kelas kemampuan lahan kelas I 2.400 bekiar $(49,6 \%)$ dengan kelas kemampuan laban kelas II, dan 62,5 bektar (1,3\%) mempunyai kelas kemampuan laban kelas IV. Kemampuan laban Kelas I menyebar pada bentuk laban Lembab Fluvial terkikis ringan dan Lereng Kaki Volkan terkikis Ringan, kelas 
II pada satuan bentuk laban Lembab Fluvial terkikis sedang dan Lereng Bawab Volkan terkikis ringan, sedangkan Kelas IV terletak pada satuan bentuk laban Lembah Fluvial terkikis berat.

Adapun faktor pengbambat pada kemampuan laban kelas II adalab erosi dan lereng, sedangkan pada Kelas IV adalab erosi, lereng, tanab dan batuan. Berdasarkan Faktor penghambat maka laban ini termasuk dalam Sub-kelas II el dan Sub-kelas IV elsb.

\section{I.PENDAHULUAN}

\section{A. LATAR BELAKANG MASALAH}

Secara Nasional masyarakat Indonesia mulai merasakan akibat peningkatan lahan kritis sebagai akibat penggunaan lahan yang tidak disesuaikan dengan kemampuan lahannya, terutama dengan adanya banjir dan kekeringan yang melanda beberapa tempat wilayah Indonesia. Lahan kritis di Indonesia saat ini luasnya sekitar 40 juta hektar yang tersebar pada 40 buah DAS (Daerah Aliran Sungai). Dari 40 buah DAS kritis tersebut ditetapkan sebagai DAS super kritis sebanyak 22 buah DAS, salah satunya adalah DAS Bengawan Solo. Disebut super kritis karena pada DAS tersebut terdapat sejumlah investasi seperti bendungan, pemukiman padat penduduk, serta seringnya terjadi banjir dan erosi setiap tahun.

Sungai Bengawan Solo merupakan sungai yang terpanjang di $P$. Jawa dengan panjang sekitar $600 \mathrm{Km}$. Luas DAS tersebut sekitar $16.100 \mathrm{Km} 2$, mempunyai curah hujan rata-rata tahunan $2.100 \mathrm{~mm}$, jumlah penduduk pada tahun 1971 sebesar $9.719 .000 \mathrm{ji}$ wa, tahun 1980 menjadi 11.268 .000 jiwa dan diperkirakan tahun 2000 nanti menjadi 15.367.000 jiwa (Imam Hidayat dkk, 1984). Permasalahan yang menonjol dalam DAS Bengawan Solo antara lain banjir pada musim hujan serta kering pada musim kamarau, erosi di daerah hulu dan sedimentasi pada sepanjang aliran sungai.

Kecamatan Kedawung yang terletak pada barat laut dari lereng gunung Lawu merupakan salah satu bagian daerah hulu DAS Bengawan Solo. Secara umum kecamatan Kedawung mempunyai kondisi relief bergelombang hingga berbukit dan kemiringan lereng miring hingga sangat miring, serta relatif banyak terjadi erosi permukaan dan alur, di beberapa tempat juga dijumpai longsoran lahan.

Dalam rangka memperoleh informasi kondisi kritis daerah kecamatan Kedawung diperlukan kajian kemampuan lahan yang merupakan aspek yang sangat penting dalam evaluasi sumberdaya lahan. Manfaat kajian kemampuan lahan ini secara umum sangatlah luas, diantaranya untuk perencanaan peng. gunaan lahan, konservasi lahan, pengelolaan daerah aliran sungai. Dalam penelitian yang penulis lakukan di Kecamatan Kedawung ini terbatas pada kajian kemampuan lahan bagi penggunaan lahan berbagai sistem pertanian secara luas.

\section{B. TUJUAN PENELITAN}

Penelitian ini bertujuan untuk:

1. Mempelajari faktor-faktor lingkungan fisik yang berpengaruh terhadap kemampuan lahan di daerah penelitian

2. Menyusun kelas kemampuan lahan dengan pendekatan satuan lahan. 


\section{TINJAUAN PUSTAKA}

Evaluasi kemampuan lahan pada dasarnya merupakan evaluasi potensi lahan untuk penggunaan berbagai sistem pertanian secara luas dan tidak membicarakan peruntukan jenis tanaman tertentu ataupun tindakan-tindakan pengelolaannya. Sifat dari evaluasi kemampuan lahan merupakan evaluasi yang lebih umum dibandingkan dengan evaluasi kesesuaian lahan yang bersifat lebih khusus.

Skema kemampuan lahan untuk evaluasi lahan pertanian telah dikembangkan oleh Departemen Pertanian Amerika Serikat (USDA) sejak setengah abad yang lalu sebagai bagian dari program untuk mengatasi erosi (Hocken Smith dan Steele, 1943; 1949; Hocken Smith, 1950, 1953; dalam Suratman Worosuprodjo, 1981) tetapi kemampuan lahan sebagai metode perencanaan penggunaan lahan, dibuat pertama kali secara eksplisit dalam sistem klasifikasi kemampuan lahan oleh USDA (Klingebiel dan Montegomery, 1961).

Sistem klasifikasi kemampuan lahan membagi lahan kedalam sejumlah kata. gori menurut faktor penghambat dan potensi bahaya lain terhadap pertum. buhan tanaman. Ada tiga katagori yang digunakan yakni kelas, sub kelas dan satuan pengelolaan (Capability unit)

Kelas merupakan tingkat tertinggi dan bersifat luas dalam struktur klasifikasi. Penggolongan ke dalam kelas didasarkan pada intensitas faktor-faktor penghambat yang permanen atau sulit diubah. Kelas kemampuan lahan berkisar dari kelas I dimana lahan mempunyai penghambat-penghambat yang sangat berat sehingga tidak memung. kinkan penggunaannya untuk produksi tanaman.

Sub kelas menunjukkan jenis faktor penghambat yang terdapat di dalam kelas. Sedangkan tingkat yang terendah dari struktur klasifikasi adalah satuan pengelolaan yang merupakan pengelompokan lahan yang mempunyai respon yang sama terhadap sistem pengelolaan tertentu. Selanjutnya struktur klasifikasi lahan berdasarkan kelas kemampuan lahan dapat dilihat pada tabel 1 berikut:

Tabel 1.1 Klasifikasi Laban Berdasarkan Kelas Kemampuan Lahan Tabel 1

\begin{tabular}{llllllllll}
\hline Karakter & \multicolumn{7}{c}{ Lahan dapat digarap Lahan tak dapat digarap } \\
lahan & I & II & III & IV & V & VI & VII & VIII \\
\hline Lereng & datar & landai & sedang & curam & curam & curam & sangat & sangat \\
& & & & & & & curam & curam \\
Kedala- & dalam & dalam & dangkal & dangkal & dangkal s dangkals. dangkal s. dangkal s. \\
man T & dalam & & sedang & & dangkal & dangkal & dangkal & dangkal \\
Tekstur & Lempung & Gelum & sedang & pasir & pasir2 & pasir & pasir & pasir pasir \\
tanah & & berpasir & lempung & bergelh & geluh & geluhan & gelhan & geluhan \\
pH tanah & $6-7$ & $5-6$, & $4,5 \cdot 5$, & $4,5-5$ & $3,5-4,5$ & $3,5-4,5$ & $3,5-4,5$ & $3,5-4,5$ \\
& & $9-8$ & $8-8,5$ & 8,5 & 8,5 & 8,5 & 8,5 & 8,5 \\
drainase & baik & sedang & sangat & jelek & jelek & sangat & sangat & sangat \\
& & & lambat & & & jelek & jelek & jelek \\
\hline
\end{tabular}




$\begin{array}{lllllllll}\begin{array}{l}\text { bahaya } \\ \text { erosi }\end{array} & \text { tiada } & \text { sedang } & \text { tinggi } & \begin{array}{l}\text { sangat } \\ \text { tinggi }\end{array} & \begin{array}{l}\text { sangat } \\ \text { tinggi }\end{array} & \begin{array}{l}\text { sangat } \\ \text { tinggi }\end{array} & \begin{array}{l}\text { sangat } \\ \text { tinggi }\end{array} & \begin{array}{l}\text { sangat } \\ \text { tinggi }\end{array} \\ \text { kahan } & \text { tiada } & \text { sedikit } & \text { sedang } & \text { banyak } & \begin{array}{l}\text { sangat } \\ \text { banyak }\end{array} & \text { sangat } & \text { sangat } & \text { sangat } \\ \text { banyak } & \text { banyak } & \text { banyak }\end{array}$

Sumber : USDA dengan modifikasi

Dalam penelitian ini klasifikasi kemampuan lahan dilakukan pada tingkat kelas yang disajikan dalam bentuk skala 1: 50.000 . Pada tingkat survei skala ini, faktor penghambat ditunjjukkan untuk mengetahui tingkat sub-ke- las pada masing-masing kelas dengan simbol huruf. Sedangkan tingkat kelas kemampuan lahan ditunjukkan dengan simbol angka romawi (lihat Tabel 1.2)

Tabel 1.2 Struktur KlasifiksiKemam. puan Lahan

\begin{tabular}{|lllll|}
\hline $\begin{array}{l}\text { Kelas } \\
\text { kemampuan }\end{array}$ & $\begin{array}{l}\text { Sub-kelas } \\
\text { Kemampuan }\end{array}$ & Ketentuan pengelolaan & $\begin{array}{l}\text { Satuan peta } \\
\text { Tanah }\end{array}$ \\
\hline I & & II c,iklim & & \\
II & dapat & II e, erosi & IIe-1 & seri X \\
III & digarap & II w, kelemahan & IIte-2 & Seri Y \\
& & II s,tanah & IIe-3 & Seri Z \\
IV & & & & \\
& & & & \\
V & II es & & \\
VI & Tll & & \\
VII & & & \\
VIII & & & \\
\hline
\end{tabular}

Sumber: Dent can Young (1981)

\section{LANDASAN TEORI}

Sesuai dengan uraian tinjauan pustaka, landasan teori yang digunakan dalam penelitian ini adalah berkaitan dengan faktor-faktor yang mempengaruhi kemampuan lahan. Di dalam penelitian ini, faktor-faktor yang mempengaruhi kemampuan lahan menggunakan modifikasi Soepraptohardjo (1962) yang terdiri dari:

a. Faktor-faktor lahan yang menguntungkan, yakni:

1. kedalaman efektif tanah

2. tekstur tanah
3. kesuburan tanah

4. $\mathrm{pH}$ tanah

5. drainase tanah

6. permeabilitas tanah

b. Faktor-faktor lahan yang merugikan, yakni:

1. kemiringan lereng

2. erosi

3. banjir

4. penggenangan

5. batu besar

6. batu kerikil

7. muka air tanah 
Data kedua faktor-faktor lahan tersebut diambil pada setiap satuan pemetaan yakni satuan bentuk lahan.
Adapun skoring data faktor-faktor lahan yang dinilai terdapat dalam tabeltabel berikut.

Tabel 1.3. Petunjuk Klasifikasi Kedalaman Efektif Tanab

\begin{tabular}{|l|c|c|}
\hline Klas & Kedalaman Efektif Cm & Skor \\
\hline Sangat dangkal & 30 & 1 \\
Dangkal & $30-69$ & 2 \\
Sedang & $60-90$ & 3 \\
Dalam & $90-120$ & 4 \\
Sangat Dalam & 120 & 5 \\
\hline
\end{tabular}

Sumber: Norman Hudson, 1973

Tabel 1.4 Petunjuk Klasifikasi Tekstur Tanab

\begin{tabular}{|lll|}
\hline Klas & Tekstur Tanah & Skor \\
\hline Halus & Lempung, lempung berpasir, lempung berdebu & 2 \\
Sedang & Geluh berlempung, debu, geluh berdebu, geluh & 3 \\
Kasar & Geluh berpasir, pasir, pasir bergeluh & 1 \\
\hline
\end{tabular}

Sumber: Norman Hudson, 1973

Tabel 1.5 Petunjuk Klasifikasi Kesuburan Tanab

\begin{tabular}{|lllllll|}
\hline Klas & $\mathrm{pH}$ & $\mathrm{N}(\%)$ & $\mathrm{P}(\%)$ & $\mathrm{K}(\%)$ & $\mathrm{Ca}$ & Skor \\
\hline Tinggi & $6,6-8$ & $>0,5$ & $>41$ & $>41$ & $>3$ & 4 \\
Sedang & $5,6-5,6$ & $0,2-0,5$ & $21-40$ & $21-40$ & $2-3$ & 3 \\
Rendah & $4,5-5,5$ & $0,1-0,2$ & $15-20$ & $10-20$ & $1-2$ & 2 \\
Sangat rendah & $<4,5$ & $<0,1$ & $<15$ & $<10$ & $<1$ & 1 \\
\hline
\end{tabular}

Sumber: Van Zuidam, 1978

Tabel 1.6. Petunjuk Klasifikasi pH Tanab

\begin{tabular}{|lll|}
\hline Klas & pH tanah & Skor \\
\hline Baik & $6,5-7,5$ & 3 \\
Sedang & $5,5-6,5$ & 2 \\
Jelek &, 5 dan 7,5 & 1 \\
\hline
\end{tabular}

Sumber: Harrop, 1974

Forum Geografi No. 10 Tahun VI / Juli 1992 
Tabel 1.7. Petunjuk Klasifikasi Drainase Tanab

\begin{tabular}{|c|c|c|}
\hline Klas & Kenampakan di Lapangan & Skor \\
\hline Baik & Tanpa ada/sedikit keratan/becak-becak & 4 \\
\hline Sedang & Karatan banyak tersebar pada profil tanah dan pada horison & \\
\hline & $80 \mathrm{Cm}$ ke bawah sering terinduksi & 3 \\
\hline Jelek & $\begin{array}{l}\text { Karatan pada bagian atas dan pada horison } 50-80 \mathrm{Cm} \\
\text { sering tereduk }\end{array}$ & 2 \\
\hline Sangat Jelek & $\begin{array}{l}\text { Karatan pada bagian atas dan pada horison } 20-50 \mathrm{~cm} \\
\text { sering tereduksi }\end{array}$ & 1 \\
\hline
\end{tabular}

Sumber: Isa Darmawijaya, 1977

Tabel 1.8. Petunjuk Klasifikasi Permeabilitas

\begin{tabular}{|lll|}
\hline Klas & Besarnya Permeabilitas & Skor \\
\hline Cepat/sangat cepat & $12,7-25,4 \mathrm{Cm} / \mathrm{jam}$ & $1+$ \\
Agak cepat & $6,35-12,7 \mathrm{Cm} / \mathrm{jam}$ & $2+$ \\
Sedang & $2,0-6,35 \mathrm{Cm} / \mathrm{jam}$ & $3+$ \\
Agak lambat & $0,5-2,0 \mathrm{Cm} /$ jam & $2+$ \\
Lambat/sangat lambat & $0,125-0,5 \mathrm{Cm} / \mathrm{jam}$ & $1+$ \\
\hline
\end{tabular}

Sumber: Modifikasi Soepraptoharjo, 1962

Tabel 1.9. Petunjuk Klasifikasi Kemiringan Lereng

\begin{tabular}{|lll|}
\hline Klas & Kemiringan Lereng (persen) & Skor \\
\hline Datar & $0-3$ & 0 \\
Agak miring & $3-8$ & $1-$ \\
Miring & $8-15$ & $2-$ \\
Agak terjal & $15-30$ & $3-$ \\
Terjal & $30-45$ & $4-$ \\
Agak curam & $45-60$ & $5-$ \\
& $>60$ & $6-$ \\
\hline
\end{tabular}

Sumber: Isa Darmawijaya, 1970

Tabel 1.10. Petunjuk Klasifikasi Erosi

\begin{tabular}{llc}
\hline Klas & \multicolumn{1}{c}{ Kenampakan di Lapangan } & Skor \\
\hline - Tanpa & $\begin{array}{l}\text { - Tidak ada lapisan tanah yang hilang, belum ada erosi } \\
\text { - Rongan }\end{array}$ & $\begin{array}{l}\text { - Sebagian tanah atas sudah hilang dan sudah ada alur- } \\
\text { alur kecil }\end{array}$ \\
- Sedang & - Tanah bagian atas dan sub soil sudah hilang sudah ada & 1- \\
\hline 16 & Forum Geografi No. 10 Tahun VI / Juli 1992
\end{tabular}


- Berat

- Lapisan tanah atas dan sub soil sebagian besar sudah hilang, serta banyak lembah-lembah

- Sangat berat - Sudah tidak ada lapisan tanah

4 -

Sumber: Harrop, 1977

Tabel 1.11. Petunjuk Klasifikasi Banjir

\begin{tabular}{|lll|}
\hline Klas & Lamanya (Bulan/Tahun) & Skor \\
\hline - Tanpa & 0 & 0 \\
- Jarang & $0-2$ & $1-$ \\
- Sering & $2-6$ & $2-$ \\
- Selalu & 6 & $3-$ \\
\hline
\end{tabular}

Sumber: Soepraptohardjo, 1962.

Tabel 1.12. Petunjuk Klasifikasi Penggenangan

\begin{tabular}{|lll|}
\hline Klas & Lama Genangan (Periode 1 Tahun) & Skor \\
\hline Tanpa & Tidak pernah tergenang air & 0 \\
Sebentar & Tergenang air kurang dari 1 bulan & $1-$ \\
Lama & Tergenang air selama 1-3 bulan & $2-$ \\
Sangat lama & Tergenang air lebih dari 3 bulan & $3-$ \\
\hline
\end{tabular}

Sumber: Harrop, 1974

Tabel 1.13. Petunjuk Klasifikasi Baru Besar

\begin{tabular}{|lll|}
\hline Klas & Kritera & Skor \\
\hline Tanpa & 0 & 0 \\
Sedikit & $10 \%$ & -1 \\
Sedang & $10-25 \%$ & -2 \\
Banyak & $25 \%$ & -3 \\
\hline
\end{tabular}

Sumber: Soepraptohardjo, 1962

Tabel 1.14. Petunjuk Klasifikasi Batu Kerikil

\begin{tabular}{|lll|}
\hline Klas & Kritera & Skor \\
\hline Tanspa & 0 & 0 \\
Sedikit & $3 \%$ & -1 \\
Sedang & $-3-15 \%$ & -1 \\
Banyak & $15 \%$ & -3 \\
\hline
\end{tabular}


Sumber: Soepraptohardjo, 1962

Tabel 1.15. Petunjuk Klasifikasi Muka Air Tanab

\begin{tabular}{|lll|}
\hline Klas & Kriteria & Skor \\
\hline Tanpa & 0 & 0 \\
Dalama & 100 sentimeter & -1 \\
Agak Dalam & $50-100$ Sentimeter & -2 \\
Dangkal & 50 sentimeter & -3 \\
\hline
\end{tabular}

Sumber: Soepraptohardjo, 1962

\subsection{Rencana Penelitian}

Langkah-langkah yang diambil untuk mencapai tujuan penelitian adalah sebagai berikut:

1. Interpretasi peta topografi untuk menyusun peta satuan bentuk lahan. Dalam proses interpretasi tersebut dibantu dengan peta geologi, peta tanah dan peta penggunaan lahan. Peta bentuk lahan hasil interpretasi kemudian dibuat peta bentuk lahan sementara, selanjutnya diuji di lapangan untuk menyusun peta satuan bentuk lahan akhir.

2. Atas dasar peta satuan bentuk lahan akhir diadakan survei lapangan terhadap faktor-faktor kemampuan lahan dan pengambilan bentuk tanah untuk analisa kesuburan tanah.

3. Penilaian terhadap faktor-faktor kemampuan lahan dengan skoring sesuai tabel yang dipakai selanjutnya dilakukan penyusunan kelas kemampuan lahan.

\section{KONDISI FISIK DAERAH PENE-} LITIAN

Penelitian ini dilakukan di Kecamatan Kedawung, Kabupaten Sragen, Jawa Tengah. Wilayahnya terletak pada sisi barat laut lereng Gunung Lawu, yang termasuk daerah tangkapan (DAS) Bengawan Solo bagian hulu. Berdasarkan pembagian fisioterapi Pulau Jawa oleh Pannekoek (1949), terletak pada mintakat tengah.

Berdasarkan Peta Geologi Jawa dan Madura lembar Jawa Tengah dari Direktorat Geologi tahun 1977 skala 1:1500.000 diperoleh data bahwa daerah penelitian terdiri dari alluvium dan hasil gunung api yang tak teruraikan. Sedangkan dari lampiran Peta Geologi lembar Surakarta dari Bemmelen tahun 1949 skala 1: 250.000 dan hasil survei lapangan litologi daerah penelitian terdiri dari aluvium, andesit dan breksi.

Dari hasil identifikasi melalui interpretasi peta dan uji lapangan, di daerah penelitian dijumpai bentukan asal fluvial dan volkanik. Dari kedua-dua bentukan asal tersebut dapat diperinci menjadi lima satuan bentuk lahan, yakni: lembah fluvial terkikis ringan, lembah fluvial terkikis sedang, lemah fluvial terkikis berat, lereng kaki volkan terkikis ringan dan lereng bawah volkan terkikis ringan.

Bentukan asal fluvial dicirikan dengan relief yang berombak dan struktur berlapis miring dari material endapan. Ketinggian tempat berkisar antara 140 - 210 meter dpal (di atas perrnuka- 
an air laut), dengan kemiringan lereng antara 3 - $16 \%$. Prosesgeomorfologi yang terjadi pada lembah fluvial menyebabkan terjadinya teras asal fluvial yang sudah tidak aktif mengalami penimbunan endapan terjadi proses pela. pukan batuan.

Bentuk asal volkanik dicirikan adanya struktur volkan dengan pola aliran radial sentrivigal. Pada lereng bawah volkan dan lereng kaki volkan dijumpai bentuk-bentuk igir yang membulat dan bentuk lembahnya yang semakin ke arah bawah semakin melebar atau berbentuk " $U$ " kondisi tebing-tebing lembah yang relatif terjal hingga agak melandai. Proses geomorfologi yang terjadi adalah erosi lembar dan alur, serta proses pelapukan batuan. Ketinggian tempat berkisar antara 143.241 meter dpal

\section{BENTUK LAHAN DAERAH PENELITIAN}

Kaitannya dengan evaluasi kemam. puan lahan, dipilihnya satuan bentuk lahan sebagai satuan pemetakan karena setiap satuan bentuk lahan mencer- minkan secara lengkap adanya perigaruh proses, sifat dan watak tanahnya, relief dan lereng, matuan dan kondisi airnya. Pengaruh yang dicerminkan tersebut berkait dengan faktor-faktor yang menguntungkan dan merugikan dalam evaluasi kemampuan lahan.

Adapun untuk memperoleh satuan pemetaan, dilakukan dua tingkatan klasifikasi berdasarkan kriteria:

(1) Proses geomorfologi utama, digunakan untuk membedakan bentukan asal

(2) relief / morfologi, struktur / litologi dan proses geomorfologi yang berlangsung untuk membedakan satuan bentuk iahan.

Proses geomorfologi utama yang mencerminkan bentukan asal, menurut Verstappen (1975 dalam Sunardi, 1985) ada sembilan, yakni bentukan asal: volkanik, fluvial, struktural, pelarutan, denudasional, organik, marine, glacial dan angin. Relief/morfologi diidentifikasi berdasarkan hubungan timbal balik antara unit relief, kemiringan lereng dan perbedaan ketinggian antara titik tertinggi dan titik terendah pada suatu permukaan lahan.

Tabel 3.1 Klasifikasi Relief

\begin{tabular}{|lcc|}
\hline Unit Relief & Kemiringan Lereng $(\%)$ & $\begin{array}{l}\text { Perbedaan Relatif titik tertinggi } \\
\text { dan terendah }(\mathrm{m})\end{array}$ \\
\hline Datar & $0-2$ & 5 \\
Berombak & $3-8$ & $5-10$ \\
Bergelombang & $8-15$ & $10-50$ \\
Berbukit & $16-21$ & $50-300$ \\
Bergunung & 21 & 300 \\
\hline
\end{tabular}

Sumber: Desaunettes, 1977 dengan modifikasi

Struktur/litologi diidentifikasi dengan bantuan Peta Geologi dan uji lapangan. Selanjutnya proses geomorfo- logi yang sedang berlangsung diidentifikasi dengan tingkat pengikisan. Tingkat pengikisan tersebut didasarkan 
pada jarak rata-rata antara cabang-cabang sungai. Klasifikasi tingkat pengi- kisan dibagi menjadi tiga tingkatan (lihat Tabel 3.2)

Tabel 3.2 Tingkat Pengikisan

\begin{tabular}{|lc|}
\hline Tingkat Pengikisan & Jarak Antar Cabang Sungai (1:50.000) \\
\hline Ringan & $2 \mathrm{Cm}$ \\
Sedang & $0,2-2 \mathrm{Cm}$ \\
Berat & $0,2 \mathrm{Cm}$ \\
\hline
\end{tabular}

Sumber: Van Zuidam, 1979 dengan modifikasi

\section{A. Satuan Bentuk lahan pada ben- tukan asal Fluvial (F)}

Bentuk asal fluvial meliputi lahan seluas 812,5 hektar, menyebar di sepanjang sungai daerah penelitian. Berdasarkan tingkat pengikisan bentukan asal fluvial dibedakan menjadi tiga satuan bentuk lahan, yakni:

(a) Lembah Fluvial terkikis ringan (FSI)

Bentuk lahan ini seluas 187,5 hektar menyebar pada lembah sungai Sragen dan Karanglo bagian bawah. Material pembentuk tanahnya merupakan hasil pengendapan dari material yang diangkut sungai dan hasil proses erosi pada bagian atasnya. Tanah yang ada sudah berkembang dengan macam tanah Latosol coklat yang dicirikan : tekstur tanahnya geluh berdebu, kedalaman efektif antar $60-90 \mathrm{~cm}$ kesuburan sedang, $\mathrm{pH}$ antara 5,5-6,5, drainase tanah sedang, permeabilitasnya sedang. Kemiringan lereng berkisar antara $3-8 \%$ (agak miring), proses erosi relatif ringan dengan alur-alur kecil, tanpa adanya banjir dan penggenangan, penyebaran batu besar dan kerikil relatif sedikit dan kedalaman muka air tanah relatif dalam.

(b) Lemah Fluival terkikis sedang (FS2)

Bentuk lahan ini seluas 562,5 hektar menyebar pada lembah sungai Sragen, Karanglo dan Mungkung dengan material perbentuk tanah merupakan hasil pengendapan yang diangkut oleh aliran sungai. Tanah yang adalah Aluvial dan Latosol dengan ciri: tekstur geluh berdebu dan geluh berpasir, kedalaman efektif tanah $30.60 \mathrm{~cm}$, kesuburan relatif sedang, $\mathrm{pH}$ berkisar 5,5 . 6,5 , drainase relatif baik, dan permeabilitas relatif agak cepat. Sedangkan kemiringan lereng berkisar antara $8-15 \%$ (miring), erosi sedang, tanpa adanya banjir dan penggenangan, penyebaran batu besar dan kerikil relatif sedikit, dengan muka air tanah dalam.

(c) Lembah Fluvial terkikis berat (FS3)

Bentuk lahan ini seluas 62,5 hektar menyebar pada sungai Mungkung bagian bawah, dengan material pembentuk tanah merupakan hasil pengendapan proses erosi lahan atasnya. Tanah yang ada adalah Aluvial yang dicirikan dengan tekstur geluh berpasir, kedalaman efektif tanah sangat dangkal, kesuburan tanah rendah, $\mathrm{pH}$ berkisar $5,5 \cdot 6,5$, drainase baik dan permeabilitas tanah relatif cepat. Adapun kemiringan lereng berkisar antara $15 \cdot 30 \%$ (agak terjal), tingkat erosi relatif berat tanpa adanya banjir dan penggenangan, penyebaran batu besar dan kerikil relatif sedang dan muka air tanah dalam. 


\section{B. Satuan Bentuk lahan pada ben- tukan asal Volkanik (V)}

Betukan asal Volkanik meliputi bagian besar daerah penelitian, dengan luas 4025 hektar atau 83,2\% luas daerah penelitian. Karakteristik relief/morfologi pada bentukan asal Volkanik ini dicirikan adanya perubahan kemiringan lereng, bentuk igir dan bentuk lembahnya yang jelas. Berdasarkan perbedaan tersebut, dapat dibedakan menjadi dua satuan bentuk lahan.

(a) Lereng Kaki Volkan terkikis ringan (VK1)

Bentuk lahan ini meliputi daerah seluas 2187,5 hektar, menyebar di bagian bawah hingga tengah daerah penelitian. Jenis tanah yang berkembang adalah Latosol dengan macam tanah Latosol coklat yang dicirikan: tekstur tanah geluh berdebu, kedalaman efek. tif relatif sedang (berkisar $60-90 \mathrm{~cm}$ ), kesuburan relatif tinggi, $\mathrm{pH}$ tanah 6,5 . 7,0 , drainase relatif baik, dan permeabilitas tanah sedang. Sedangkan keadaan kemiringan lereng relatif agak miring (3-2\%), proses erosi relatif ringan, tanpa adanya banjir dan genangan, dengan kedalaman muka air tanah relatif dalam.

(b) Lereng Bawah Volkan Terkikis Ringan (VL1)
Bentuk lahan ini meliputi daerah seluas 1837,5 hektar menyebar pada bagian tengah atas daerah penelitian. Jenis tanah yang berkembang adalah Latosol, dengan macam tanahnya Latosol coklat yang dicirikan: kedalaman efektif tanah relatif sedang berkisar antara $60.90 \mathrm{~cm}$, tekstur geluh berpasir, kesuburan tanah relatif sedang, $\mathrm{pH}$ tanah sedang, drainase relatif baik, dengan permeabilitas tanah relatif agak cepat: Sedangkan kemiringan lereng berkisar antara 8 - 15\% (miring), erosinya relatif ringan, tanpa adanya banjir dan genangan, penyebaran batu besar dan kerikil relatif sedang, dengan kedalaman air tanah sangat dalam.

\section{KEMAMPUAN LAHAN DAERAH PENELITIAN}

Penilaian kemampuan lahan dalam penelitian ini menggunakan pendekatan skoring terhadap faktor-faktor yang menguntungkan dan yang merugikan. Dari jumlah nilai/skor kemudian diklasifikasikan untuk mengetahui kelas kemampuan lahan.

Adapun klasifikasi kelas kemampuan lahan dengan menggunakan Tabel 4.1 berikut

Tabel. 4.1. Kelas Kemampuan Lahan

\begin{tabular}{|lll|}
\hline Kelas & & Jumlah \\
\hline I & Dapat dikerjakan & $>=12$ \\
II & Dapat dikerjakan & $>-11$ \\
III & Dapat dikerjakan & $2-6$ \\
IV & Dapat dikerjakan & $-3-1$ \\
V-VIII & Tidak dapat dikerjakan & $<-3$ \\
\hline
\end{tabular}

Sumber: Soepraptohardjo dengan modifikasi 
Setelah diperoleh informasi kelas kemampuan lahan ini, dilakukan evaluasi untuk mengetahui jenis faktor penghambat yang terdapat di dalam kelas sehingga didapatkan sub kelas kemampuan lahan.

Berdasarkan hasil pengamatan pada 15 titik pengamatan yang menyebar bentuk lahan di daerah penelitian diperoleh nilai skor masing-masing faktor kemampuan lahan. Adapun hasil pengukuran faktor yang mempengaruhi kemampuan lahan disajikan pada Tabel 4.2. berikut. (lihat tabel) .

Dari persebaran kelas kemampuan lahan di daerah penelitian, dapat diketahui bahwa pada satuan bentuk la. han.

Lembah Fluvial terkikis ringan dan Lereng Kaki Volkan terkikis ringan mempunyai kelas kemampuan lahan Kelas II, sedangkan satuan bentuk lahan Lembah Fluvial terkikis berat mempunyai kelas kemampuan lahan Kelas IV.

Daerah penelitian secara keseluruhan merupakan lahan yang dapat digarap, tetapi diperlukan penanganan khusus dalam penggarapannya. Pada Kelas I secara umum sesuai untuk segala macam penggunaan pertanian karena keadaan tanah relatif mudah diolah, dapat menahan air dengan baik dan responsif terhadap pemupukan. Lahan Kelas I ini tidak mempunyai penghambat atau ancaman kerusakan yang berarti dan cocok untuk usaha ta. ni intensif. Tindakan pencegahan terhadap gejala erosi alur perlu diusahakan, pemupukan dan pemeliharaan struktur tanah diperlukan untuk mempertahankan kesuburan dan produktivitas lahannya.

Pada lahan Kelas II mempunyai sedikit penghambat yang dapat mengurangi pilihan penggunaan lahannya, ter- utama keadaan lereng dan proses erosi. Dalam penggunaannya diperlukan tindakan-tindakan pengawetan tanah dengan pengolahan tanah menurut garis kontur, pergiliran tanaman atau guludan. Dalam pembagian Sub Kelas maka pada lahan Kelas II ini termasuk Sub Kelas II el. yakni faktor penghambat yang terdapat dalam kelas adalah erosi dan lereng.

Pada lahan Kelas IV ini mempunyai penghambat yang cukup besar sehing. ga mengurangi pemilihan jenis penggunaan lahannya. Adapun faktor penghambat yang ada adalah tanah, erosi, lereng dan penyebaran batu besar dan kerikil. Penggunaan lahan untuk tanaman semusim pada lahan ini diperlukan pembuatan teras atau saluran drainase yang baik. Berdasarkan faktor-faktor penghambat tersebut maka lahan tersebut termasuk dalam Sub Kelas IV elsb yakni lahan Kelas IV yang mempu. nyai faktor penghambat erosi, lereng, tanah dan penyebaran batuan.

\section{v. KESIMPULAN}

(1) Dari hasil klasifikasi kelas kemampuan lahan, dinyatakan bahwa daerah penelitian seluas: 2375 hektar $(49,1 \%)$ mempunyai kelas kemampuan lahan Kelas I 2400 hektar $(49,5 \%)$ dengan kelas kemampuan lahan Kelas II, dan 62,5 hektar $(1,3 \%)$ mempunyai kelas kemam. puan lahan Kelas IV.

(2) Kemampuan lahan Kelas I menyebar pada bentuk lahan Lembah Fluvial terkikis ringan (FSI) dan Lereng Kaki Volkan terkikis ringan (VK1): kelas II pada satuan bentuk lahan Lembah Fluvial terkikis sedang (FS2) dan Lereng Bawah Volkan terkikis ringan (VL1); sedangkan 
Kelas IV pada satuan bentuk lahan Lembah Fluvial terkikis berat (FS3).

(3) Faktor penghambat kemampuan lahan Kelas II adalah erosi dan le- reng, sedangkan pada kelas IV adalah erosi lereng, tanah dan batuan.

\section{DAFTAR PUSTAKA}

Bemmelen, R,W. Van, 1949, Geology of Indonesia Vol.I. General Geology Adjacent Archipelago Goverment Office The Haque.

Desaunettes, JR., 1977. Cataloque Landforms for Indonesia Bogor: Soil Reseach Institue.

Karmono Mangunsukardjo, 1985. Interpretasi Citra untuk Inventarisasi Sumberdaya Lahan. Yogyakarta: PUSPICS-Fakultas Geografi. Universitas Gajah Mada.

Pannekoek. A.J, 1949. Outline of The Geomorphology of Java Haarlem: Geological Survey.

Santun R.P. Sitorus, 1985. Evaluasi Sumberdaya Lahan. Bogor: Jurusan Ilmu Tanah. Institut Pertanian Bogor.

Schmidt, F.H., and Ferguson, J.H.A, 1951 Rainfall Types Based on Wet and Dry Period Rotation for Indonesia With Western New Guinea, Werhandelingen No.42. Jakarta: Kementrian Perhubungan Djawatan Meteorologi dan Geofisika.

Sunardi Joyosuharto, 1983. Penyusunan Skripsi Program Studi S1 Bidang Studi Geomorfologi dan Sumberdaya Lahan. Fakultas Geografi, Universitas Gajah Mada.

kemam

wa dae.

hektar

kemam-

hektar

ampuan

hektar

kemam.

1985. Dasar-Dasar Pemikiran Klasifikasi Bentuk lahan. Fakultas Geografi. Universitas Gajah Mada.

Zuidam, R.A, and Van Zuidam Canselando, 1979. Terrain Analysis and Clasifikation using aerial Photographs, A Geomorphological Approach. ITC Texbook of Photo Interpretation VII-6. Enchede: ITC 


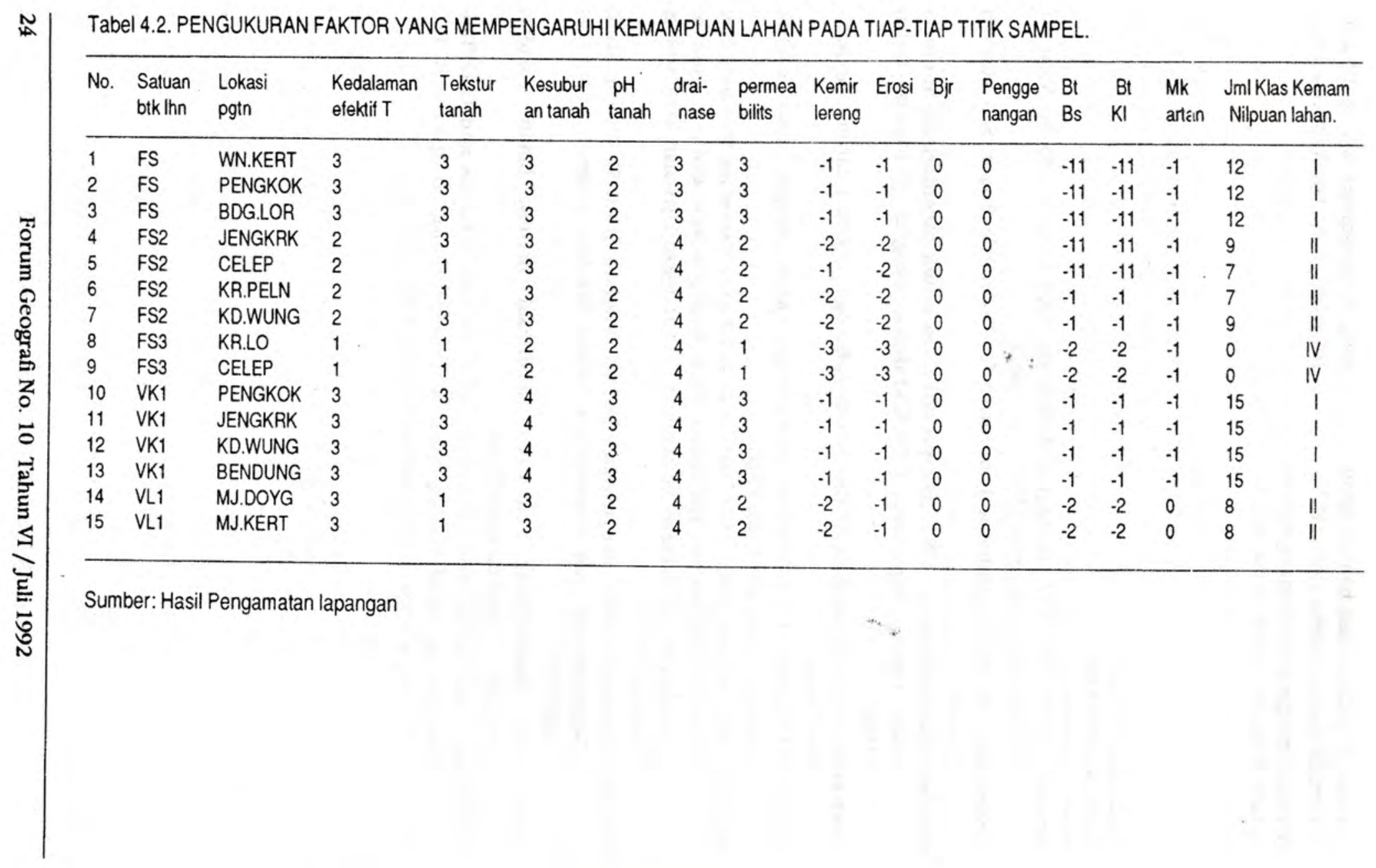






Disusun aleh: Kuswaj Dui Priyono/-5ia? 